\title{
THE CORRELATION BETWEEN STUDENTS' ANXIETY AND STUDENTS' ACHIEVEMENT IN LEARNING ENGLISH
}

\section{KORELASI ANTARA KECEMASAN SISWA DAN PRESTASI SISWA DALAM PEMBELAJARAN BAHASA INGGRIS}

\author{
Dea Ann Pratiwi ${ }^{1}$, Sulastri Manurung 2 \\ English Education Department, University of Riau Kepulauan, Indonesia \\ 1.
}

\begin{abstract}
ABSTRAK
Tujuan dari penelitian ini adalah untuk menemukan hubungan antara kecemasan siswa dengan prestasi belajar siswa dalam pembelajaran Bahasa Inggris. Desain dari penelitian ini merupakan penelitian korelasi yag terdiri dari dua variabel, yaitu variabel bebas dan variabel terikat. Teknik pengambilan sampel merupakan probability sampling dengan cluster random sampling. Sampel penelitian ini adalah 38 siswa kelas X IIS SMAN 8. Foreign Language Classroom Anxiety Scale (FLCAS) oleh Horwitz digunakan untuk mengukur tingkat kecemasan siswa. Instrumen untuk mengukur prestasi siswa adalah tes diagnostik yang terdiri dari tes mendengar dan pemahaman membaca. Setelah menguji validitas dan reliabilitas dengan menggunakan SPSS V.16.0, peneliti mendistribusikan tes ke sampel. Kemudian, peneliti menganalisis korelasi dengan menggunakan Product Moment Formula oleh Pearson untuk mengkorelasikan kecemasan siswa (variabel X) dan prestasi siswa (variabel Y). Hasil penelitian menunjukkan bahwa r hitung atau korelasi pearson adalah 0,092. Tabel $r$ untuk 39 responden adalah 0,312. Ini berarti bahwa $r$ hitung lebih rendah dari $r$ tabel dan Ha ditolak dan Ho diterima. Hitungan $r$ menunjukkan -0.092. Oleh karena itu, ada korelasi negatif yang signifikan antara Kecemasan Siswa dan Prestasi Siswa dalam belajar bahasa Inggris siswa kelas X Sekolah Menengah Atas 08 Batam.
\end{abstract}

Kata Kunci; korelasi, kecemasan siswa, prestasi belajar siswa

\begin{abstract}
The objective of the study was to find out the correlation between students' anxiety and students' achievement in learning English. The research design was correlational research which consisted of two variables, independent and dependent variable. The sampling technique was probability sampling with cluster random sampling. The sample in this research was thirty nine students of X8 social class of SMAN 08 Batam. Foreign Language Classroom Anxiety Scale (FLCAS) by Horwitz was addressed to check the existence of students' anxiety. The instrument to measure the students' achievement was a diagnostic test which consists of listening and reading comprehension test. After tested the validity and reliability of the test by using SPSS V.16.0, the researcher distributed the test to the sample. Then, the researcher analysed the correlation by using Product Moment Formula by Pearson to correlate both students' anxiety ( $X$ variable) and students' achievement ( $Y$ variable). The result showed that the $r$ count or Pearson correlation was 0.092. The $r$ table for 39 respondents is 0.312. It means that $r$ count is lower than $r$ table and Ha is rejected and Ho is accepted. The $r$ count showed -0.092. Hence, there was significant negative correlation between Students' Anxiety and Students' Achievement in learning English at the tenth grade students of Senior High School 08 Batam.
\end{abstract}

Keywords: correlation, students' anxiety, students' achievement 


\section{INTRODUCTION}

English is one of the international languages which has succeed and used by most of the big countries in the entire of the world. English has been used as a tool of communication among most of different countries around the world including in education. However, in Indonesia, English is taught as one of the foreign languages. English as a foreign language only used by a standardized international school which using English language in daily communication, whereas a standardized national school used English only in the English lesson and mostly taught grammatical rules of the target language. It caused students find it difficult to acquire English even after learning it for 12 years in schools.

Based on the researcher observation in teaching students at Senior High School 08 Batam, especially for tenth grade students, most students faced some difficulties in learning English. They could not answer a simple question by using English and were afraid of making mistakes whether in listening or reading. They also face difficulties in comprehending a text and responding to the audio or someone speech. Therefore, they could not answer the questions related the text or monologue they listened. However, to acquire a good language skill, it requires the four language skills including listening, reading, writing, and speaking skills.

Students' achievement is a result achieved by the students in learning process. According to Suryabrata (2003:324), there are internal and external factors that influenced students' achievement which internal factors include of psychology and physical factors, while external factors include of environmental and instrumental factors. Internal factors consist of health, enthusiasm and motivation, anxiety, and learning habit whereas external factors consist of family, school, society, and environment. It means that anxiety is part of internal factors which influenced students' achievement and feeling too much anxiety in learning process can make the students got a low score.

Language anxiety is more or less present in every person. There is a problem in using English in a minority of language user. It is not effective if learning English only exist at school without the implementation through daily life activities. There is a huge possibility that anxiety present in every student because they feel lack of ability in using English. Horwitz (1986:125) defined anxiety as the subjective feeling of tension, apprehension, nervousness, and worry associated with an arousal of the 
autonomic nervous system. It means that the students who are not able to answer the teachers' question will be worry and feel anxious.

Regarding to the point of the existing of anxiety in foreign language learning, investigating the correlation between students' anxiety towards their learning achievement can be useful and positive indicators of the important of reducing anxiety in foreign language learning to make language learning relaxed, smooth, easy and interesting that resulted in better language achievement. Therefore, the research aims at investigating the correlation between the students' anxiety and their learning achievement in learning English as foreign language in the context of Senior High School 8 Batam.

\section{Definition of Anxiety}

Anxiety has been defined by some scholars especially in the terms of language learning and educational psychology. Spielberger (1983) defines anxiety as the subjective feeling of tension, apprehension, nervousness, and worry associated with an arousal of the nervous system. Horwitz (1986) defines foreign language anxiety as a distinct complex of self-perceptions, beliefs, feelings, and behaviors related to classroom language learning arising from the uniqueness of the language learning process. These definitions led the researcher into a conclusion that language anxiety refers to someone's self-feeling and thoughts towards the uniqueness of language learning process. The uniqueness mostly preferred as the complexity of language learning.

\section{Causes for Anxiety}

Anxiety in language learning is caused by several factors that affect students' performance in acquiring the language whether from the students themselves or their environment. Tanveer (2007:58) found that language anxiety can originate from within and outside of the language classroom environment which include psycholinguistic (related to learner's cognition and language learning difficulties, classroom environment, fear of making mistakes, linguistics difficulties) and sociocultural factors like cultural differences, social status and self-identity, gender, etc. Oda\&Khammat (2013:48) also stated that the reasons for feeling anxiety in English classrooms are the closely related to the students themselves and some other external factors.

Moreover, anxiety also contributes both to students learning achievement and attitudes toward language learning. Hu and Wang (2014:23) described two causes of 
anxiety, namely learner's personality and attitudes towards learning and teachers' attitude; students class style and learning experience. Learner's personality and attitudes towards learning include self-esteem and introversion. Self-esteem means a self-judgment of worth value, based on feeling of efficacy, a sense of interacting effectively with one's environment. Meanwhile, introversion considered as less apt language learners. Wu (2010:189) suggested that the impact of anxiety-provoking causes should be taken into serious consideration. Therefore, it is the teachers' duty to create a less threatening atmosphere, to motivate, and to strengthen student confidence as more motivated students tend to be more successful language learners.

\section{Classification of Anxiety}

In addition Spielberger (1986) stated that a distinction can be made between the three categories that provide an important insight to our understanding of foreign or second language anxiety as follows:

\section{Trait anxiety}

Trait anxiety is a permanent predisposition to be anxious. Some people are predictably and generally anxious about many things. It is almost same as fear and it can make ability of people to overcome the resources are lost.

\section{State anxiety}

State Anxiety occurs as an emotional reaction to the current situations. It is experienced in relation to some particular event or act.

\section{Situation-Specific anxiety}

It caused by specific situation or event such as public speaking, examinations or recitations. Among these types of anxiety, situation-specific anxiety occurs mostly in case the students are in test-taking situation. The anxiety also occurs when students have to speak in front of the class or in public during speaking activity.

On the other hand, Shabani (2012: 2379) describes three varieties of foreign language anxiety firstly; communication apprehension occurs in cases where learners lack mature communications skills although they have mature ideas and thoughts, secondly, test anxiety is an apprehension towards academic evaluation, and finally fear of negative evaluation which refers to avoidance of negative evaluative situations. Anxiety not only exists on young learners but also adult learners as well. Although students have ideas or thoughts to share, they feel worry or anxious when 
they have to express in English. They fear of making mistakes and being judged by their evaluator or friends.

\section{Effects of Language Anxiety}

Some researches related to language learning anxiety that claim it has both positive and negative effects. Anxiety exists in academic can cause serious effect on students' performance in foreign language learning. Hashempour\&Mehrad (2014:119) state that academic anxiety can negatively impact on schools activity success and activities as anxious children is self-preoccupying, most of their energy which can be used in their learning process and help to raise their academic succession are wasted and leads to undesirable consequences. Thus, students will show lack of interest and passion in learning process and as consequence may result in poor performance especially in language learning. However, the positive effect from language anxiety can lead to an improved performance. Anxiety can motivate someone in learning foreign language. Hu\&Wang (2014) classified anxiety into Cicek (2014) stated the importance aspect of anxiety is the way in which and individual process a threatening situation. Thus, their anxiety is influence of their perspective towards the threatening and how they deal with the situation.

In a study that investigated students' reactions to speaking, Young (as cited in Minat, 2013), discovered that students consider speaking activities that require "on the spot" and "in front of everyone" performance to be the most anxiety provoking. Communication apprehension, social anxiety, and low self-esteem were considered three vital components of language anxiety. When making a mistake in a language classroom, students often worry that they are negatively evaluated, not only by their instructor, but also by their classmates. Thus, the students avoid having speaking activities in the class because they are afraid of being judged not only by the teacher but also the classmates.

\section{The Concept of Learning English}

In learning English language, the students demand to be able in four skills which are reading, writing, listening and speaking. According to Mundhe (2015:1), these skills can be grouped differently: reading and listening are receptive skills as they used in receiving information and speaking and writing are productive skills as they are useful for producing and conveying information. According to Mundhe (2015:6), language is an integrative activity so it is wise to teach language skills 
interactive, more than one skill at a time. It means that the teacher should develop the students' skill by involving more than one skill at a time.

According to Brown (2004), in foreign language learning, reading is likewise a skill that teachers simply expect learners to acquire. Basic, beginning-level textbooks in a foreign language presuppose a student's reading ability if only because it's a book that is the medium. In assessing reading, covers the comprehension of these features: main idea (topic), expressions/idioms/phrases in context, inference (implied detail), grammatical features, detail (scanning for a specifically stated detail), excluding facts not written (unstated details), supporting idea(s), vocabulary in context. It means that through reading students can improve their knowledge and develop it into some brilliant ideas because reading is essential skill in learning foreign language.

Meanwhile according to Wallace.et.al (2004:13), listening skill is essential for learning since teachers enable students to acquire insights and information and to achieve success in communicating with others. In addition, Brown (2004) stated that, in assessing listening, these stages represent a potential assessment objective: comprehending of surface structure elements such a phoneme, word, intonation, or a grammatical category, understanding of pragmatic context, determining meaning of auditory input, and developing the gist, a global or comprehensive understanding. Therefore, the teacher can teach the students the strategy in listening, such as only listen for specific kinds of information e.g. the main purposes, the themes and the details.

\section{Learning Achievement}

Learning is an activity to get knowledge as a result of an experience. According to Slavin (as cited in Brown, 2004), learning is a change in an individual caused by experience. In line with Slavin (as cited in Pritchad, 2009), states that learning is the process of gaining more knowledge or of learning how to do something. The result of learning can be seen by the achievement. Based on the Alkin (1982), achievement refers to accomplishment and carries the connotation that accomplishments follow a period of study, training or practice. It means that learning achievement is the result that reflected the ability of the students in learning English.

Hence, the learning achievement is a form of result and it depends on the student itself. Then, the researcher involved listening and reading skill to see the result of students' learning achievement. 


\section{METHODOLOGY}

This research is quantitative research method and used correlational research. According to Sugiyono (2010:135), this method is a scientific method, because it has filled the scientific principles that are concrete or empirical, objective, measurable, rational, and systematic. The researcher conducted the research at Senior High School 08 Batam, specifically at the tenth grade students. The population of this sample was 360 which are divided into 9 classes. The technique sampling that used to this research was probability sampling with cluster random sampling because each group or class got the same opportunity to be a sample. 39 students of X8 social class were chosen as the respondent class. The instrument used to examine the students' anxiety (X) was Foreign Language Classroom Anxiety Scale (FLCAS) by Horwitz (1986) which consist of 33 valid and reliable items in close from and used Likert scale. The instrument to measure students' achievement (Y) was diagnostic tests which consist of 15 items of listening skills and 50 items of reading comprehension test and tested it to $\mathrm{X} 7$ social class (exclude the sample). The researcher tested the validity and reliability of diagnostic tests before distributed to the sample.

\section{RESULTS}

The results of this research were obtained by using Foreign Language Classroom Anxiety Scale (FLCAS) and diagnostic tests with the aim of the research to find out the correlation between students' anxiety and students' achievement in learning English at the tenth grade students of Senior High School 08 Batam.

Foreign Language Classroom Anxiety Scale (FLCAS)

Table. 1. Data description of FLCAS result

\begin{tabular}{ccccccccc} 
N & $\begin{array}{c}\text { Possible } \\
\text { Range }\end{array}$ & Range & Mean & Median & Mode & SD & Min & Max \\
\hline 39 & $33-165$ & $58-136$ & 103.69 & 103.00 & 97 & 13.826 & 58 & 136 \\
\hline
\end{tabular}

From the calculation of a questionnaire containing 33 items of statements, the total FLCAS scores ranged between 58 (the score indicating the lowest anxiety level in this group) and 136 (the score indicating the highest anxiety level in this group), with an average score of 103.69. There is a wide variability in scores shown by the large standard deviation (13.826) related to the level of students' anxiety. 
Pratiwi and Manurung: The Correlation between Student's Anxiety...

Table. 2. Data description of students' level of anxiety

\begin{tabular}{cccc} 
Level & Class Boundaries & Frequency & Percentage \\
\hline Low & $58-98$ & 14 & $35.8 \%$ \\
Moderate & $99-107$ & 12 & $30.76 \%$ \\
High & $109-136$ & 13 & $33.33 \%$ \\
\hline
\end{tabular}

The table above told that there are 3 levels of Students' Anxiety; they are low anxiety (58-98), moderate (99-101), and high anxiety (109-136). For the first level only 3 learners in percentage $35.8 \%, 30.76 \%$ for moderate level and $33.33 \%$ in high level. The highest number comes in low level.

Diagnostic Tests

Table. 3. Data description of valid items

Items

Total

\begin{tabular}{llr}
\hline Valid Items & $1,2,3,4,5,6,7,8,9,11,12,13,14,15,16,17,18,19,20,21,22$ & \\
& $, 23,24,25,26,27,28,29,30,31,32,33,34,35,36,37,38,40,41$, & \\
& $42,43,44,46,47,48,49,50,51,53,54,55,56,57,58,60,61$, & 60 \\
& $62,63,64,65$. & 5 \\
Invalid items & $10,39,45,52,59$ &
\end{tabular}

From the calculation of validity test by SPSS V.16.0, there are only 60 items that valid and only 5 items that invalid. The researcher only took 10 items for listening test and 30 items for reading comprehension test from valid item and constructs the valid items based on the indicators from syllabus.

Table. 4. Data description of Reliability Test

\begin{tabular}{ccccc} 
& $\begin{array}{c}\text { Cronbach's } \\
\text { alpha }\end{array}$ & $\begin{array}{c}\text { Parameter } \\
\text { Reliable }\end{array}$ & N of Items & Status \\
\hline $\begin{array}{c}\text { Listening } \\
\text { Test }\end{array}$ & 0.803 & 0.60 & 14 & Reliable \\
$\begin{array}{c}\text { Reading } \\
\text { Test }\end{array}$ & 0.942 & 0.60 & 46 & Reliable \\
\hline
\end{tabular}

From the calculation of reliability test, $0.803>0.60$ it means the 14 items of listening test were reliable and $0.942>0.60$ it means the 46 items of reading comprehension test were reliable too. 
Table. 5. Data description of diagnostic tests result

\begin{tabular}{rrrrrrrr} 
N & Range & Mean & Median & Mode & SD & Min & Max \\
\hline 39 & $45-90$ & 69.03 & 68.00 & 62 & 12.608 & 45 & 90 \\
\hline
\end{tabular}

From the result of diagnostic tests which contain 10 items of listening skill and 30 items of reading comprehension test. It is obtained the range for minimum score of 45 and maximum score of 90 . The average score (mean) is 69.03. From the data, it is obtained standard deviation of 12.608. Before the data is analyzed by using Product Moment Correlation by Pearson, and then first research assumptions test is done which is Normality Test. The normality test is performed to determine whether the data has normally distributed. The data were the distribution of data on the FLCAS and diagnostic tests. Normality test of the data used One-sample Kolmogorov Smirnov Test.

Table. 6. Normality Test

\begin{tabular}{|c|c|c|}
\hline \multicolumn{3}{|c|}{ Unstandardized Residual } \\
\hline $\mathrm{N}$ & & 39 \\
\hline \multirow[t]{2}{*}{ Normal Parameters ${ }^{\mathrm{a}}$} & Mean & .0000000 \\
\hline & Std. Deviation & 12.55086309 \\
\hline \multirow[t]{3}{*}{ Most Extreme Differences } & Absolute & 111 \\
\hline & Positive & .094 \\
\hline & Negative & -.111 \\
\hline Kolmogorov-Smirnov Z & & .693 \\
\hline Asymp. Sig. (2-tailed) & & .722 \\
\hline
\end{tabular}

By comparing sig. with value for alpha $=0.05$. It can be concluded the sig. (2tailed) of One-Sample Kolmogorov-Smirnov Test is 0.722 . Hence, $0.722>0.05$ it means the data were distributed normally.

\section{Finding the correlation}

Table. 7. Data description of Hypothesis test

\begin{tabular}{llrr} 
& & Students'Anxiety & Students'Achievement \\
\hline \multirow{2}{*}{ Students'Anxiety } & & 1 & -.092 \\
& Pearson Correlation & & .579 \\
& Sig. (2-tailed) & 39 & 39 \\
& $\mathrm{~N}$ & & \\
\hline \multirow{2}{*}{ Students'Achievement } & Pearson Correlation & $\mathbf{. 0 9 2}$ & 1 \\
& Sig. (2-tailed) & .579 & 39 \\
& N & 39 & 39 \\
& & & \\
\hline
\end{tabular}


Pratiwi and Manurung: The Correlation between Student's Anxiety...

The analysis was by comparing the Pearson correlation or $r$ count with $r$ table, because $\mathrm{r}$ count $<0.312$, it means that Ho is accepted, and $\mathrm{Ha}$ is rejected. In the coefficient correlation value, there is negative sign which means there was negative correlation between Students' Anxiety and Students' Achievement. The Pearson correlation score is -0.092 where $r$ ranges from $0.00-0.1999$. This means that there is very low correlation between students' anxiety (X) and students' achievement (Y) in learning English at the tenth grade students of Senior High School 08 Batam.

\section{DISCUSSION}

As stated previously, the research aimed to investigate any potential correlation between students' anxiety towards their language learning achievements. Thus, the following discussion will explain deeply.

The research finding shows there is negative correlation between students' anxiety and students' achievement in learning English at the tenth grade students of Senior High School 08 Batam. It means the increase anxiety in learning English is resulted in decreasing of the students score. The result shows clearly that anxiety has negative impact towards students' achievement in foreign language learning. On the contrary, students who have lower anxiety in learning English tend to have higher score. Accordingly, the finding is in line with those previous researches Horwitz (1986), Amiri\&Ghoonsoly (2015), Halder (2018) which reported the negative correlation between anxiety and achievement in language learning.

Regarding on the above finding and discussion, the researcher suggested to remove or reduce English learning anxiety both by the teachers and students. Teachers should be able to create enjoyable learning activities, friendly classroom environment and give more time and effort to overcome the students' anxiety. As Amiri (2015:861) suggested, teachers should tolerate the mistakes made by the students and inform them that making mistakes is inevitable in learning a foreign language. Sharifi (2015:39) emphasized students need an environment free from intimidation and feelings of inadequacy so they can link complex thinking with appropriate use of language.

\section{REFERENCES}

Amiri, M.\&Ghoonsoly, B. 2015. The Relationship between English Learning Anxiety and the Students' Achievement on Examination. Journal of Language Teaching and Research. Vol 6(4). 855-865. 
Pratiwi and Manurung: The Correlation between Student's Anxiety...

Brown, H. Douglas. (2004). Language Assessment: Principle and Classroom Practices. ISBN 0-13-098834-0. Retrieved from https://books.google.co.id/books/about/Language_Assessment.html?id=NaglA QAAIAAJ\&redir_esc $=y$

Čiček,Lana. (2014). Language Anxiety-Causes and Consequences.Graduation Thesis.University of Zagreb. 1-49

Halder, U.K. 2018. English Language Anxiety and Academic Achievement. North Asian International Research Journal of Social Science \&Humanities. Vol 4(3). 138-147.

Hashempour, S.\&Mehrad, A. 2014. The Effect of Anxiety and Emotional Intelligence on Students' Learning Process. Journal of Education \& Social Policy. Vol 1(2). 115-122.

Horwitz, Elaine K., Horwitz, Michael B., \& Cope, Joann. (1986). Foreign Language Classroom Anxiety. The Modern Language Journal. 70 (2).125-132.

$\mathrm{Hu}$, Ling\&Wang, Na. (2014). Anxiety in Foreign Language Learning. International Conference on Global Economy, Commerce and Service Science (GECSS). Atlantis Press. 122-124.

Minat, Numaya. (2013). An Investigation Of English Language Anxiety Experiences Of Undergraduate Students In Bangladesh (Doctoral Dissertation). Retrieved from http://hdl.handle.net/10361/3555

Mundhe, Ganesh B. (2015). Teaching Receptive and Productive Language Skill with the Help of Techniques. An International Journal in English, Vol 1(1).

Oda, A.H\&Khammat, A. H.2013. Investigating the Factors that Cause Language Anxiety in Iraqi EFL Learners. Journal of Basrah Researches (Humanities Series). Vol 38(2). 25-53.

Pritchard, Alan. (2009). Ways for Learning: Learning Theories and Learning Styles in the Classroom ( $2^{\text {nd }}$ ed.). ISBN 0-203-88724-7 Master e-book ISBN. Retrieved from www.epitropakisg.gr/grigorise/ways\%20of\%20learning.pdf

Sharifi, F.\&Laskharian, A. 2015. Relationship between Anxiety in Speaking Ability of EFL Learners. Journal of Applied Linguistics. Vol 1(3). 31-41.

Spielberger, C.D. (1983). Manual for the State-Trait Anxiety (From Y). Consulting Psychologist Press. Palo Alto. CA.

Sugiyono, (2010). Metode Penelitian Kuantitatif Kualitatif \& RND. Bandung: Alfabeta

Suryabrata, S. (2003). Pendidikan Belajar Mengajar di Perguruan Tinggi. Yogyakarta: Andi Offset.

Tanveer, Muhammad. 2007. Investigation of the Factors that Cause Language Anxiety for ESL/EFL Learners in Learning Speaking Skill and the Influence it 
Pratiwi and Manurung: The Correlation between Student's Anxiety...

Casts on Communication in the Target Language. Dissertation. University of Glasgow: Scotland, UK.

Wallace, Trudy, Stariha, Winifred E., \& Walberg, Herbert J. (2004). Teaching speaking, listening and writing. International Academy of Education. Retrieved from http://www.ibe.unesco.org

Wu, Kun-huei. (2010). The Relationship between Language Learners' Anxiety and Learning Strategy in the CLT Classroom. International Education Studies. Vol.3(1). 174-191. 